\title{
Growth of the Skull of Norwegian Lynx
}

\author{
Trond ANDERSEN \& Øystein WIIG
}

\begin{abstract}
Andersen T. \& Wiig Ø., 1984: Growth of the skull of Norwegian lynx. Acta theriol., 29, 8: 89-100 [With 3 Tables \& 6 Figs.]

Age related variation in 16 skull dimensions of male and female lynx Lynx lynx (Linnaeus, 1758) recorded, based on a collection of 281 specimens (156 males and 125 females) caught in different parts of Norway during the ten year period 1960 to 1969 . Three main growth patterns were recognized: most skull dimensions were found to increase with age, while the lengths of the carnassials were unrelated to age and the breadth of the postorbital constriction decreased with age. The dimensions increasing with age all showed a period of rapid growth during the first year of life leveling off during the first half of the second year. The decrease of the postorbital constriction followed an inverse pattern. This means that cessation of the rapid postnatal growth coincides with the attainment of puberty. Several of the skull dimensions showed a slow, but continuous growth also in animals older than 17 months. This growth was studied in detail by analyses of means of the age classes and by analyses of regression. The growth pattern in males and females seemed to differ. Males had a continuous growth until the age of about 3 to 4 years, whereas the growth of the females stopped after about 3 years. The implications of ontogenetic variation in adults for studies of geographic variation are discussed.

[Dept. of Systematic Zoology, Zoological Museum, University of Bergen, N-5000 Bergen, Norway]
\end{abstract}

\section{INTRODUCTION}

Growth has three quantitative aspects of special interest to zoologists, firstly the change over time in some dimensions of an animal, secondly the relative size of two dimensions, and thirdly the change of shape (Simpson et al., 1960). When sampling for growth, several procedures can be followed (Tanner, 1951; Simpson et al., 1960; Cock, 1966). The most commonly used are successively measuring parts affected by growth of a single or a group of living animals (e.g. Lombaard, 1971; Kidwell et al., 1979), or measuring random population samples of animals of known age or age group. The latter procedure has been followed by several authors trying to establish age criteria for the animals; the body parts measured have been e.g. eye-lenses (e.g. Dudzinski \& Mykytowycz, 1961; Friend, 1967; Hagen et al., 1980), or baculum (e.g. Hewer, 1964 Walton, 1968).

If the growth pattern is to be established, an accurate age determination of the individuals studied is essential. Morris (1972) provided a com- 
prehensive review of various methods of age determination of mammals. Until recently the methods used have often been based on growth curves or on rather subjective criteria like the rate of closure of cranial sutures, the shape of cranial processes or ridges, surface texture or density and solidity of bones etc. (e.g. Wood, 1958; Hysing-Dahl, 1959; Churcher, 1960). Most of these criteria result from physiological processes and as such they are expressions of the rate of aging within the individual organism rather than an indication of its chronological age. As a results, most studies of growth have been concerned with the phase of rapid growth in young animals only, and it has often been stated that it is unknown whether the growth continues throughout life (e.g. Gould \& Kreeger, 1948). During the last decades the utilization of annual layering in the dentin or cementum of the teeth have proved to be a successful method for aging a variety of mammals with great accuracy (see Grue \& Jensen, 1979 for a review). The establishment of the exact age of wild animals permits comparisons to be made between age and e.g. morphometric traits also in older specimens (Stephenson, 1977).

In the present paper we present the growth of several skull dimensions of Norwegian lynx Lynx lynx (Linnaeus, 1758), based on a random sample accurately aged from incremental annuli in the cementum tooth root (Kvam, 1979). Only growth in its strictest sense, i.e. the change over time in the various dimensions measured, has been treated. We have established the age at which the rapid postnatal growth ceases and have been particularly concerned with ontogenetic variation in older animals.

\section{MATERIAL AND METHODS}

\subsection{Material}

Skulls with mandibles from a total of 281 lynx (156 males and 125 females) were used in the present study. The animals have been hunted in most parts of Norway, but mainly in the four counties Sør-Trøndelag, Nord-Trøndelag, Nordland and Troms, during the ten year period, 1960 to 1969 . The carcasses were sent to The Norwegian Game Research (DVF Viltforskningen) in order to collect a shooting reward. The skeletons are now deposited at the Zoological Museum, University of Bergen.

The specimens have been sex-identified from internal sex-organs and aged from incremental annuli in the cementum of the canine tooth root as described by Reimers \& Nordby (1968) at The Norwegian Game Research. The age of specimens younger than 1.5-2 years, when the first dark zone in the tooth root is formed, were set to the number of months between an estimated date of birth (15. May) to the date of capture, allowing for two age classes (Kvam, 1979). 


\subsection{Measurements}

The following 16 skull dimensions were measured by a calliper and recorded to the nearest $0.1 \mathrm{~mm}$ (Fig. 1):

1. Mandible length $(M L)$ : from Infradentale to the angular process.

2. Mandible height $(M H)$ : from the basal point of the angular process to Coronion.

3. Mandible dental length $(M D L)$ : from the anterior margin of the $I_{1}$ alveolus to the posterior margin of the $\mathrm{M}_{1}$ alveolus.

4. $\mathrm{M}_{1}$ length $(M 1 L)$ : total anterior-posterior length measured at the cingulum.
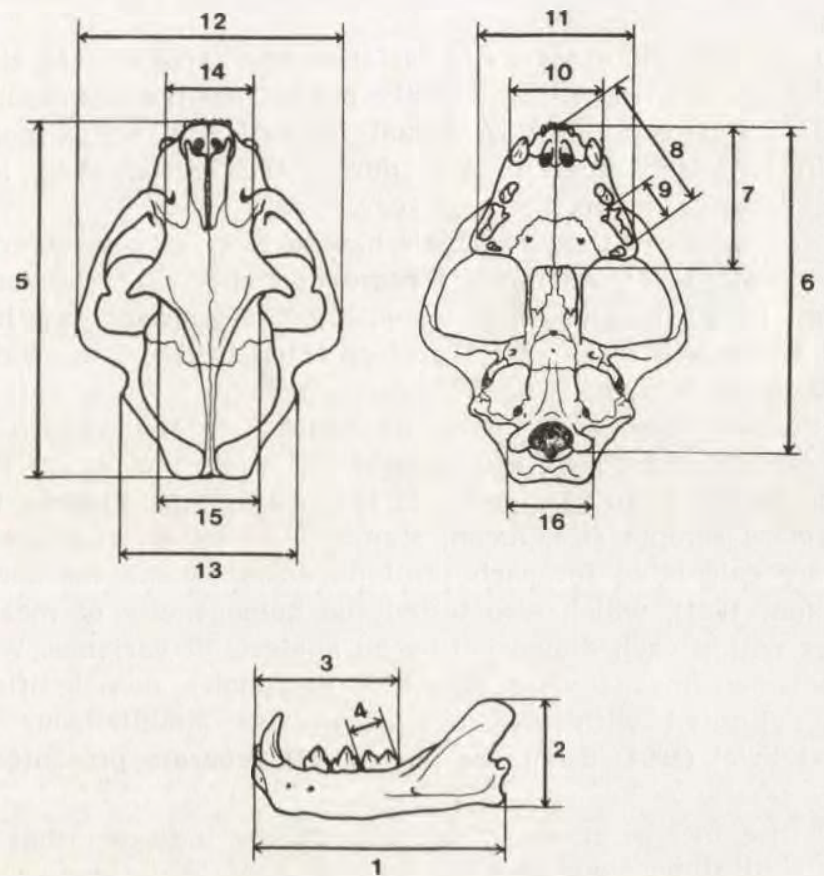

Fig. 1. Measured skull dimensions of Lynx lynx.

1 - Mandible length $(M L), 2$ - Mandible height $(M H), 3$ - Mandible dental length $(M D L), 4-\mathrm{M}_{1}$ length $(M 1 L), 5$ - Profile length $(P L), 6$ - Condylobasal length $(C B L), 7$ - Palatal length $(P L), 8$ - Dental length $(D L), 9$ - $\mathrm{P}^{4}$ length $(P 4 L), 10$ - Rostrum breadth $(R B), 11$ - Dental breadth $(D B), 12$ - Zygomatic breadth $(Z B), 13$ - Mastoid breadth $(M B), 14$ - Interorbital constriction (IC), 15 - Postorbital constriction $(P C), 16$ - Condyl breadth $(C B)$.

5. Profile length $(P L)$ : from Prosthion to Akrokranion.

6. Condylobasal length $(C B L)$ : from Prosthion to posterior border of the occipital condyl.

7. Palatal length $(P A L)$ : from Prosthion to Staphylion.

8. Dental length $(D L)$ : from Prosthion to the posterior border of the $\mathrm{P}^{4}$ alveolus.

9. $\mathrm{P}^{4}$ length $(P 4 L)$ : total anterior-posterior length measured at the cingulum.

10. Rostrum breadth $(R B)$ : between the outer margin of the canine alveoles.

11. Dental breadth $(D B)$ : between the outer margin of the $\mathrm{P}^{4}$ alveoles. 
12. Zygomatic breadth $(Z B)$ : greatest breadth between the zygomatic arches.

13. Mastoid breadth $(M B)$ : greatest breadth between the mastoid processes.

14. Interorbital constriction (IC): least breadth between the orbits.

15. Postorbital constriction $(P C)$ : jest breadth of the postorbital constriction.

16. Condyl breadth $(C B)$ : greatest lateral breadth of the occipital condyl.

Many of the skulls are to a lesser or greater degree damaged, thus in several cases all measurements could not be made.

\subsection{Statistical Analysis}

As the lynx show a clear sexual size dimorphism (Wiig \& Andersen, in press) the sexes are treated separately.

In order to describe the ontogenetic variation, the value of each size measurement of all skull dimensions studied was firstly plotted against age, using the computer program BMDP6D (Dixon, 1981). A visual inspection of these plots indicate that the growth in lynx nearly terminates during the second year, in fact most of the growth takes place during the first year.

It is generally assumed that mammals have a more or less deterministic growth (e.g. Simpson et al., 1960). Asymptotic regression curves of the form $y=a+b e^{-k t}$, where $y=$ mean length at an age of $t$ months, $a=$ asymptotic length, $b=$ integration constant, and $k=$ growth rate, were therefore fitted to the data, using the computer program BMDP3R (Dixon, 1981).

In order to determine statistically at which age the growth evens out the material was separated into six age classes: 1) 1 to 11 months, 2) 12 to 17 months, 3) 18 to 23 months, 4) 24 to 35 months, 5) 36 to 59 months, 6) older than 59 months. In each age class sample size, mean, standard deviation, coefficient of variation, and range were calculated for each skull dimension, using the computer program BMDP7D (Dixon, 1981), which also tested the homogeneity of means over all the six age classes within each dimension by an analysis of variance. Where significant differences between means were detected, maximally non-significant subsets of means were delimited with the sum of squares simultaneous test procedure (SS-STP) of Gabriel (1964) using the Fortran-IV program presented by Sokal and Rohlf (1969).

Increase of the means in the older age classes indicates that the growth of several of the skull dimensions does not fit a deterministic growth model. Therefore, linear regression lines were fitted to the measurements of individuals older than 17 months, and the significance of these regressions were tested by an analysis of variance, using the computer program BMDP6R (Dixon, 1981). A further analysis of the four oldest age classes was performed by the SS-STP test procedure after an analysis of variance between their means, as described above. Although both the analysis of variance and the analysis of linear regression test the same null hypothesis, no age dependent variation, the test of linear regression is more powerful against the alternative hypothesis, that a linear relationship between the dependent (size) and the independent (age) variable exist. Thus, when the dependent variable increases slightly as the independent increases, the mean square among groups may not reach significance by an analysis of variance, yet a significant regression can be found (Sokal \& Rohlf, 1981).

A significant linear regression between one of the dimensions measured and age means that a significant proportion of the variation in the dimension can be explained by variation in age. But this does not necessarily mean that the growth of the dimension in question is linear. To establish in which area of the 
age range the growth can be considered as linear a test of departure from linear regression was performed. The computer program BMDP5R (Dixon, 1981) was applied; which tested the goodness of fit of a polynomal of first degree by testing for additional information in the orthogonal polynomals of second and third degree. A significant result indicates that the data are better fitted to a curvilinear than to a linear model.

\section{RESULTS}

\subsection{General Growth Patterns}

The plots of the measurements against age indicate the existence of three major patterns of ontogenetic variation: 1) Most of the skull dimensions increase with age, although the rate of growth in the various dimensions varies. The growth of the rostrum breadth (RB) of males and

Table 1

Sample size $(\mathrm{n})$, range $(\mathrm{R})$, mean $(\overline{\mathrm{x}})$, standard deviation $(\mathrm{s})$, and coefficient of variation (v) of 16 skull measurements within 6 age classes of male and female lynx from Norway.

\begin{tabular}{|c|c|c|c|c|c|c|}
\hline \multicolumn{7}{|c|}{ Males } \\
\hline & $\begin{array}{c}1-11 \\
\text { months }\end{array}$ & $\begin{array}{l}12-17 \\
\text { months }\end{array}$ & $\begin{array}{l}18-23 \\
\text { months }\end{array}$ & $\begin{array}{l}24-35 \\
\text { months }\end{array}$ & $\begin{array}{l}36-59 \\
\text { months }\end{array}$ & $\begin{array}{l}>59 \\
\text { months }\end{array}$ \\
\hline & 1. $M L$ & & & & & \\
\hline $\mathrm{n}$ & 27 & 4 & 38 & 33 & 26 & 17 \\
\hline $\mathrm{R}$ & $60.9-93.3$ & $92.4-102.5$ & $88.6-106.2$ & $96.8-108.2$ & $99.5-108.2$ & $93.4-110.4$ \\
\hline$\overline{\mathrm{x}}$ & 79.56 & 97.43 & 102.03 & 102.52 & 105.05 & 104.98 \\
\hline $\mathbf{s}$ & 7.47 & 4.60 & 4.17 & 2.88 & 2.15 & 3.85 \\
\hline \multirow[t]{2}{*}{$\mathbf{v}$} & 9.4 & 4.7 & 4.1 & 2.8 & 2.0 & 3.7 \\
\hline & 2. $M H$ & & & & & \\
\hline $\mathrm{n}$ & 28 & 4 & 39 & 34 & 27 & 16 \\
\hline $\mathbf{R}$ & $25.8-41.0$ & $43.2-47.5$ & $39.1-49.4$ & $43.3-51.3$ & $43.5-51.1$ & $42.7-52.3$ \\
\hline$\overline{\mathrm{x}}$ & 34.35 & 44.65 & 45.66 & 46.74 & 48.08 & 47.60 \\
\hline $\mathbf{s}$ & 3.86 & 1.96 & 2.50 & 2.03 & 1.62 & 2.59 \\
\hline \multirow[t]{2}{*}{$\mathbf{v}$} & 11.2 & 4.4 & 5.5 & 4.3 & 3.4 & 5.4 \\
\hline & 3. $M D L$ & & & & & \\
\hline $\mathrm{n}$ & 27 & 4 & 39 & 33 & 26 & 17 \\
\hline $\mathrm{R}$ & $35.1-53.0$ & $54.1-57.0$ & $49.4-59.8$ & $52.2-60.5$ & $55.5-59.8$ & $54.3-60.3$ \\
\hline$\overline{\mathrm{x}}$ & 47.79 & 55.43 & 56.38 & 56.49 & 57.72 & 57.86 \\
\hline $\mathrm{s}$ & 4.69 & 1.32 & 2.00 & 1.79 & 1.08 & 1.41 \\
\hline \multirow[t]{2}{*}{$\mathrm{v}$} & 9.8 & 2.4 & 3.5 & 3.2 & 1.9 & 2.4 \\
\hline & 4. $M 1 L$ & & & & & \\
\hline $\mathrm{n}$ & 22 & 4 & 40 & 33 & 25 & 17 \\
\hline $\mathrm{R}$ & $14.0-16.0$ & $15.1-16.5$ & $13.8-16.9$ & $14.7-17.2$ & $11.5-16.3$ & $1 \div .4-16.4$ \\
\hline $\overrightarrow{\mathrm{x}}$ & 15.30 & 15.83 & 15.63 & 15.58 & $156 ?$ & 15.64 \\
\hline s & .54 & .61 & .57 & .58 & .49 & .48 \\
\hline v & 3.5 & 3.9 & 3.6 & 3.7 & 3.1 & 3.1 \\
\hline & 5. $P L$ & & & & & \\
\hline $\mathrm{n}$ & & 3 & 37 & 33 & $\because 5$ & 16 \\
\hline $\mathrm{R}$ & $96.4-139.0$ & $141.0-154.1$ & $133.0-159.0$ & $144.9-161.1$ & $148.0-161.1$ & $142.6-161.5$ \\
\hline$\overline{\mathbf{x}}$ & 122.60 & 146.90 & 150.60 & 153.61 & 155.90 & 156.20 \\
\hline s & 10.67 & 6.65 & 6.10 & 3.75 & 3.48 & 4.81 \\
\hline$v$ & 8.7 & 4.5 & 4.1 & 2.4 & 2.2 & 3.1 \\
\hline
\end{tabular}




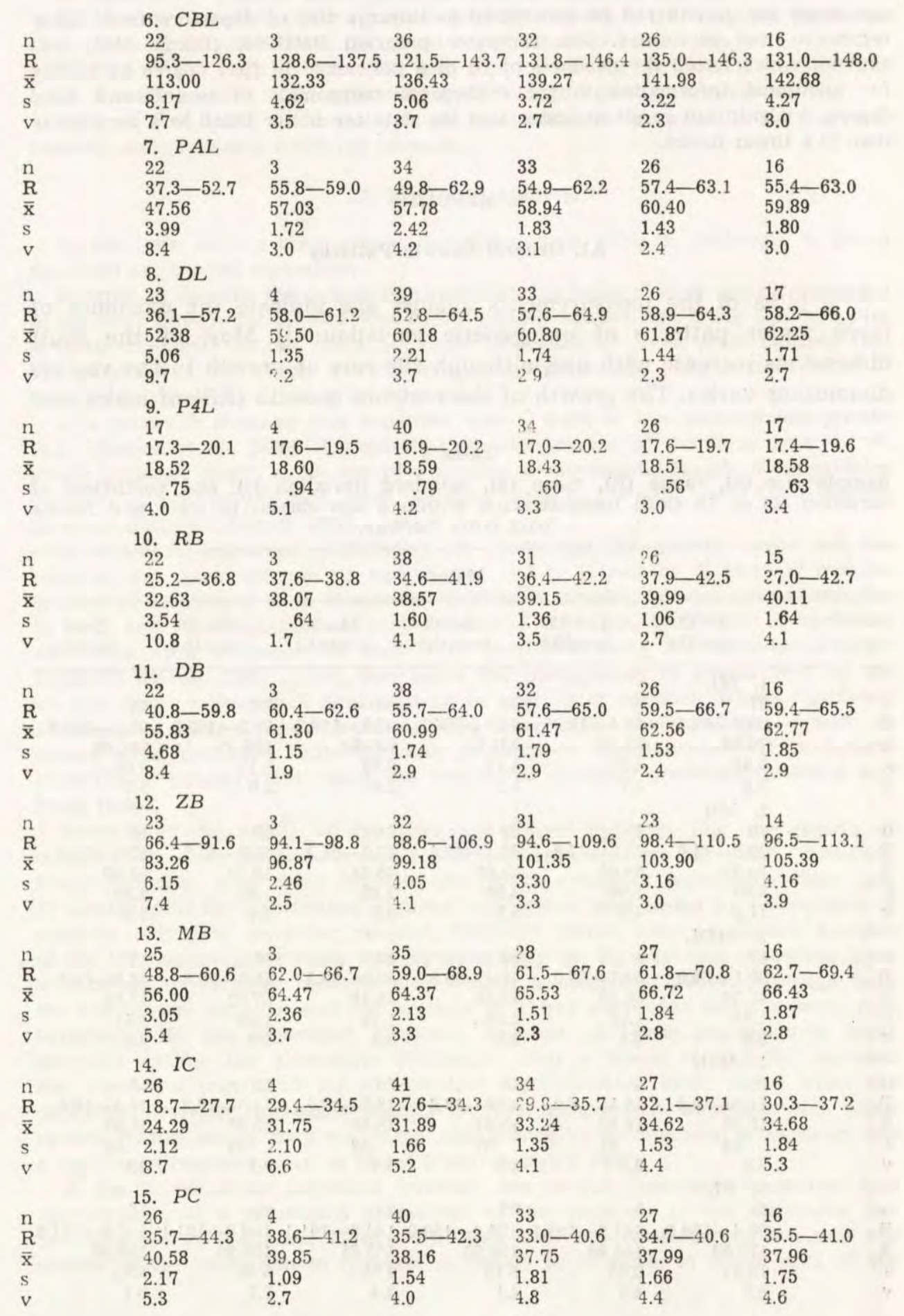


16. $C B$

\begin{tabular}{lllllll}
$\mathrm{n}$ & 16. & & & & & \\
$\mathrm{R}$ & 24 & 3 & 37 & 32 & 27 & 16 \\
$\mathrm{R}$ & $28.7-34.7$ & $33.0-34.1$ & $30.8-35.6$ & $32.3-35.8$ & $32.4-35.8$ & $32.7-34.9$ \\
$\overline{\mathrm{x}}$ & 32.16 & 33.43 & 33.51 & 34.10 & 34.33 & 33.92 \\
$\mathrm{~s}$ & 1.52 & 1.59 & 1.13 & .86 & 1.05 & .72 \\
$\mathrm{v}$ & 4.7 & 4.8 & 3.4 & 2.5 & 3.1 & 2.1 \\
\hline
\end{tabular}

Females

\begin{tabular}{|c|c|c|c|c|c|c|}
\hline & $\begin{array}{l}1-11 \\
\text { months }\end{array}$ & $\begin{array}{l}12-17 \\
\text { months }\end{array}$ & $\begin{array}{l}18-23 \\
\text { months }\end{array}$ & $\begin{array}{l}24-35 \\
\text { months }\end{array}$ & $\begin{array}{c}36-59 \\
\text { months }\end{array}$ & 59 months \\
\hline $\mathrm{n}$ & ${ }_{21}^{1 .} M L$ & 8 & 25 & 22 & 27 & 11 \\
\hline $\mathrm{R}$ & $68.3-89.1$ & $82.4-98.5$ & $87.1-99.0$ & $88.2-99.6$ & $92.2-102.6$ & $93.5-102.1$ \\
\hline$\overline{\mathrm{x}}$ & 79.98 & 89.44 & 94.62 & 95.68 & 97.57 & 97.92 \\
\hline $\mathrm{s}$ & 6.87 & 5.11 & 3.34 & 2.72 & 2.61 & 3.08 \\
\hline \multirow[t]{2}{*}{$\mathrm{v}$} & 8.6 & 5.7 & 3.5 & 2.8 & 2.7 & 3.1 \\
\hline & ${ }_{22}^{2 .} M H$ & 8 & 26 & 22 & 27 & \\
\hline $\mathrm{R}$ & $28.8-39.3$ & $36.1-43.3$ & $\begin{array}{l}20 \\
38.8-47.0\end{array}$ & $39.1-45.7$ & $40.0-46.3$ & $39.9-45.7$ \\
\hline$\overline{\mathrm{x}}$ & 34.67 & 39.19 & 41.95 & 42.33 & 43.04 & 43.11 \\
\hline $\mathbf{s}$ & 3.50 & 2.47 & 1.70 & 1.68 & 1.94 & 1.89 \\
\hline \multirow[t]{2}{*}{$\mathrm{v}$} & 10.1 & 6.3 & 4.1 & 4.0 & 4.5 & 4.4 \\
\hline & $\begin{array}{l}\text { 3. } M D L \\
21\end{array}$ & 8 & 26 & 22 & 27 & \\
\hline $\mathrm{R}$ & $39.7-53.2$ & $49.0-56.6$ & $48.7-58.4$ & $50.9-56.4$ & $52.4-58.2$ & $52.6-57.7$ \\
\hline$\overline{\mathrm{x}}$ & 47.64 & 52.64 & 53.20 & 53.66 & 54.42 & 55.24 \\
\hline $\mathrm{s}$ & 4.20 & 2.16 & 1.94 & 1.42 & 1.50 & 1.68 \\
\hline \multirow[t]{2}{*}{$\mathrm{v}$} & 8.8 & 4.1 & 3.6 & 2.6 & 2.8 & 3.0 \\
\hline & 4. $M 1 L$ & & & & & \\
\hline $\mathrm{n}$ & 16 & 8 & 26 & 22 & 27 & 11 \\
\hline $\mathrm{R}$ & $14.3-15.9$ & $14.7-16.1$ & $13.6-16.0$ & $13.6-15.7$ & $13.0-16.2$ & $14.2-16.0$ \\
\hline$\overline{\mathrm{x}}$ & 15.10 & 15.21 & 14.88 & 14.83 & 14.89 & 15.11 \\
\hline $\mathrm{s}$ & .47 & .49 & .65 & .63 & .69 & .60 \\
\hline \multirow[t]{2}{*}{$v$} & 3.1 & 3.2 & 4.4 & 4.2 & 4.6 & 4.0 \\
\hline & 5. $P L$ & & & & & \\
\hline $\mathrm{n}$ & $\begin{array}{l}18 \\
103.8-135.9\end{array}$ & $\begin{array}{l}8 \\
124,2-144.5\end{array}$ & $\begin{array}{l}22 \\
130.7-150.3\end{array}$ & $\begin{array}{l}20 \\
129.9-148.4\end{array}$ & $\begin{array}{l}23 \\
139,1-152.2\end{array}$ & $\begin{array}{l}8 \\
140.8-151.4\end{array}$ \\
\hline $\overrightarrow{\mathrm{x}}$ & 122.93 & 134.51 & 141.19 & 142.77 & 145.62 & 146.70 \\
\hline $\mathrm{s}$ & 9.86 & 6.34 & 4.79 & 4.56 & 3.88 & 4.61 \\
\hline \multirow[t]{2}{*}{ 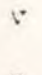 } & 8.0 & 4.7 & 3.4 & 3.2 & 2.7 & 3.1 \\
\hline & 6. $\mathrm{CBL}$ & & & & & \\
\hline $\mathrm{n}$ & 17 & 8 & 22 & 20 & 23 & 8 \\
\hline $\mathrm{R}$ & $93.0-125.2$ & $114.1-131.9$ & $119.8-134.7$ & $120.5-136.7$ & $126.8-140.2$ & $127.5-138.6$ \\
\hline$\overline{\mathrm{x}}$ & 112.36 & 123.08 & 128.57 & 130.46 & 133.27 & 133.73 \\
\hline s & 9.80 & 5.42 & 4.05 & 4.01 & 3.67 & 3.93 \\
\hline \multirow[t]{2}{*}{$\mathrm{v}$} & & 4.4 & 3.2 & 3.1 & 2.8 & 2.9 \\
\hline & 7. $P A L$ & & & & & \\
\hline $\begin{array}{l}n \\
R\end{array}$ & & 7 & 23 & $\begin{array}{l}21 \\
480-597\end{array}$ & $\begin{array}{l}22 \\
529-608\end{array}$ & 11 \\
\hline$\overline{\mathrm{x}}$ & $\begin{array}{l}39.2-56.2 \\
48.10\end{array}$ & $49.1-56.2$ & $49.0-58.9$ & $\begin{array}{l}48.0-59.7 \\
55.26\end{array}$ & $\begin{array}{l}52.9-60.8 \\
56.04\end{array}$ & $\begin{array}{l}55.1-59.5 \\
57.24\end{array}$ \\
\hline $\mathrm{s}$ & $\begin{array}{l}48.10 \\
4.36\end{array}$ & $\begin{array}{l}53.30 \\
2.52\end{array}$ & $\begin{array}{l}54.77 \\
2.28\end{array}$ & $\begin{array}{l}55.26 \\
2.60\end{array}$ & $\begin{array}{l}56.04 \\
1.87\end{array}$ & $\begin{array}{l}57.24 \\
1.71\end{array}$ \\
\hline \multirow[t]{2}{*}{$\mathrm{v}$} & 9.1 & 4.7 & 4.2 & 1.7 & 3.3 & 3.0 \\
\hline & 8. $D L$ & & & & & \\
\hline $\mathrm{n}$ & & $8-1$ & 24 & 22 & 25 & \\
\hline R & $38.8-58.7$ & $52.7-59.3$ & $53.6-60.9$ & $53.7-60.2$ & $55.5-61.1$ & $56.3-60.9$ \\
\hline$\overline{\mathrm{x}}$ & 51.24 & 55.73 & 56.80 & 57.53 & 58.14 & 58.95 \\
\hline $\mathrm{s}$ & 5.18 & 2.00 & 1.96 & 1.68 & 1.49 & 1.51 \\
\hline $\mathbf{r}$ & 10.1 & 3.6 & 3.5 & 2.9 & 2.6 & 2.6 \\
\hline
\end{tabular}




\begin{tabular}{|c|c|c|c|c|c|c|}
\hline & 9. $P 4 L$ & & & & & \\
\hline n & 14 & 8 & 26 & 22 & 27 & 11 \\
\hline $\mathbf{R}$ & $16.6-18.5$ & $17.4-19.8$ & $16.8-19.5$ & $15.9-19.6$ & $16.0-18.9$ & $16.7-19.1$ \\
\hline$\overline{\mathbf{x}}$ & 17.67 & 18.26 & 17.96 & 17.75 & 17.61 & 17.96 \\
\hline $\mathbf{s}$ & .68 & .79 & .62 & .70 & .78 & .68 \\
\hline$v$ & 3.8 & 4.3 & 3.5 & 3.9 & 4.4 & 3.8 \\
\hline & 10. $R B$ & & & & & \\
\hline n & 15 & 8 & 25 & 22 & 23 & 11 \\
\hline $\bar{R}$ & $27.0-36.6$ & $34.6-38.0$ & $32.7-38.8$ & $34.0-38.2$ & $34.8-38.6$ & $36.0-38.8$ \\
\hline$\overline{\mathbf{x}}$ & 32.99 & 35.80 & 36.26 & 36.60 & 37.24 & 37.50 \\
\hline s & 3.10 & 1.08 & 1.52 & 1.22 & .96 & .79 \\
\hline $\mathrm{v}$ & 9.4 & 3.0 & 4.2 & 3.3 & 2.6 & 2.1 \\
\hline & 11. $D B$ & & & & & \\
\hline n & & 8 & 24 & 21 & 23 & 11 \\
\hline R & $42.8-61.0$ & $56.0-60.7$ & $55.4-61.4$ & $54.4-61.0$ & $56.7-62.5$ & $54.8-60.5$ \\
\hline$\overline{\mathrm{x}}$ & 55.71 & 58.16 & 58.60 & 58.78 & 59.29 & 58.70 \\
\hline $\mathbf{s}$ & 4.12 & 1.67 & 1.61 & 1.56 & 1.51 & 1.60 \\
\hline $\mathrm{v}$ & 7.4 & 2.9 & 2.7 & 2.7 & 2.5 & 2.7 \\
\hline & 12. $Z B$ & & & & & \\
\hline $\mathrm{n}$ & 14 & 6 & 22 & 18 & 21 & 9 \\
\hline $\mathbf{R}$ & $72.3-92.0$ & $89.0-94.1$ & $87.2-100.9$ & $85.6-100.6$ & $92.9-103.7$ & $94.3-102.0$ \\
\hline$\overline{\mathbf{x}}$ & 83.85 & 91.32 & 94.45 & 94.98 & 97.15 & 98.16 \\
\hline s & 7.33 & 1.85 & 2.98 & 3.40 & 2.97 & 2.73 \\
\hline v & 8.7 & 2.0 & 3.2 & 3.6 & 3.1 & 2.8 \\
\hline & 13. $M B$ & & & & & \\
\hline $\mathrm{n}$ & 16 & 8 & 23 & 21 & 23 & 7 \\
\hline $\mathbf{R}$ & $50.7-6) .4$ & $55.9-61.7$ & $56.8-67.0$ & $576-64.8$ & $60.4-64.9$ & $59.9-64.0$ \\
\hline$\overline{\mathbf{x}}$ & 55.72 & 59.19 & 61.35 & 61.79 & 62.41 & 62.27 \\
\hline s & 3.26 & 1.77 & 1.97 & 1.67 & 1.30 & 1.37 \\
\hline $\mathrm{v}$ & 5.9 & 3.0 & 3.2 & 2.7 & 2.1 & 2.2 \\
\hline & 14. IC & & & & & \\
\hline $\mathrm{n}$ & 20 & 7 & 25 & 21 & 21 & 11 \\
\hline $\mathbf{R}$ & $22.4-28.7$ & $26.0-29.9$ & $26.5-32.8$ & $28.2-34.4$ & $29.6-33.5$ & $30.7-35.3$ \\
\hline$\overline{\mathbf{x}}$ & 24.83 & 28.03 & 30.27 & 31.08 & 31.87 & 32.16 \\
\hline s & 1.92 & 1.46 & 1.54 & 1.48 & .91 & 1.18 \\
\hline $\mathrm{v}$ & 7.7 & 5.2 & 5.1 & 4.8 & 2.9 & 3.6 \\
\hline & 15. $P C$ & & & & & \\
\hline $\mathrm{n}$ & 21 & 7 & 24 & 21 & 25 & 10 \\
\hline $\mathbf{R}$ & $38.3-46.3$ & $37.3-41.1$ & $35.2-42.5$ & $35.1-42.4$ & $34.7-41.3$ & $36.1-41.0$ \\
\hline$\overline{\mathbf{x}}$ & 41.35 & 39.09 & 38.95 & 38.09 & 38.15 & 38.59 \\
\hline s & 1.98 & 1.24 & 1.88 & 2.02 & 1.55 & 1.56 \\
\hline $\mathrm{v}$ & 4.8 & 3.2 & 4.8 & 5.3 & 4.1 & 4.0 \\
\hline & 16. $C B$ & & & & & \\
\hline $\mathrm{n}$ & & 8 & 23 & 21 & 24 & 8 \\
\hline R & $26.7-33.5$ & $30.5-34.8$ & $29.9-34.8$ & $31.4-34.6$ & $31.2-34.6$ & $32.4-34.6$ \\
\hline$\overline{\mathbf{x}}$ & 31.62 & 32.70 & 32.40 & 33.03 & 32.88 & 33.43 \\
\hline $\mathrm{s}$ & 1.72 & 1.45 & 1.04 & .91 & .93 & .64 \\
\hline $\mathrm{v}$ & 5.4 & 4.4 & 3.2 & 2.8 & 2.8 & 1.9 \\
\hline
\end{tabular}

females are illustrated in Figs. 2a and 3a. The growth is particulary rapid during the first year, a pattern found more or less in thirteen of the dimensions studied; 2) The carnassial lengths ( $M 1 L$ and $P 4 L$ ) vary independently of age (Fig. 2b); 3) The postorbital constriction (PC) decreases with age in both sexes (Figs. 2c, 3b).

Table 1 gives basic statistics for all dimensions studied. The analysis of variance of homogenity of means over all age classes showed significant deviations $(P<0.05)$ in 14 of the dimensions in both sexes. 

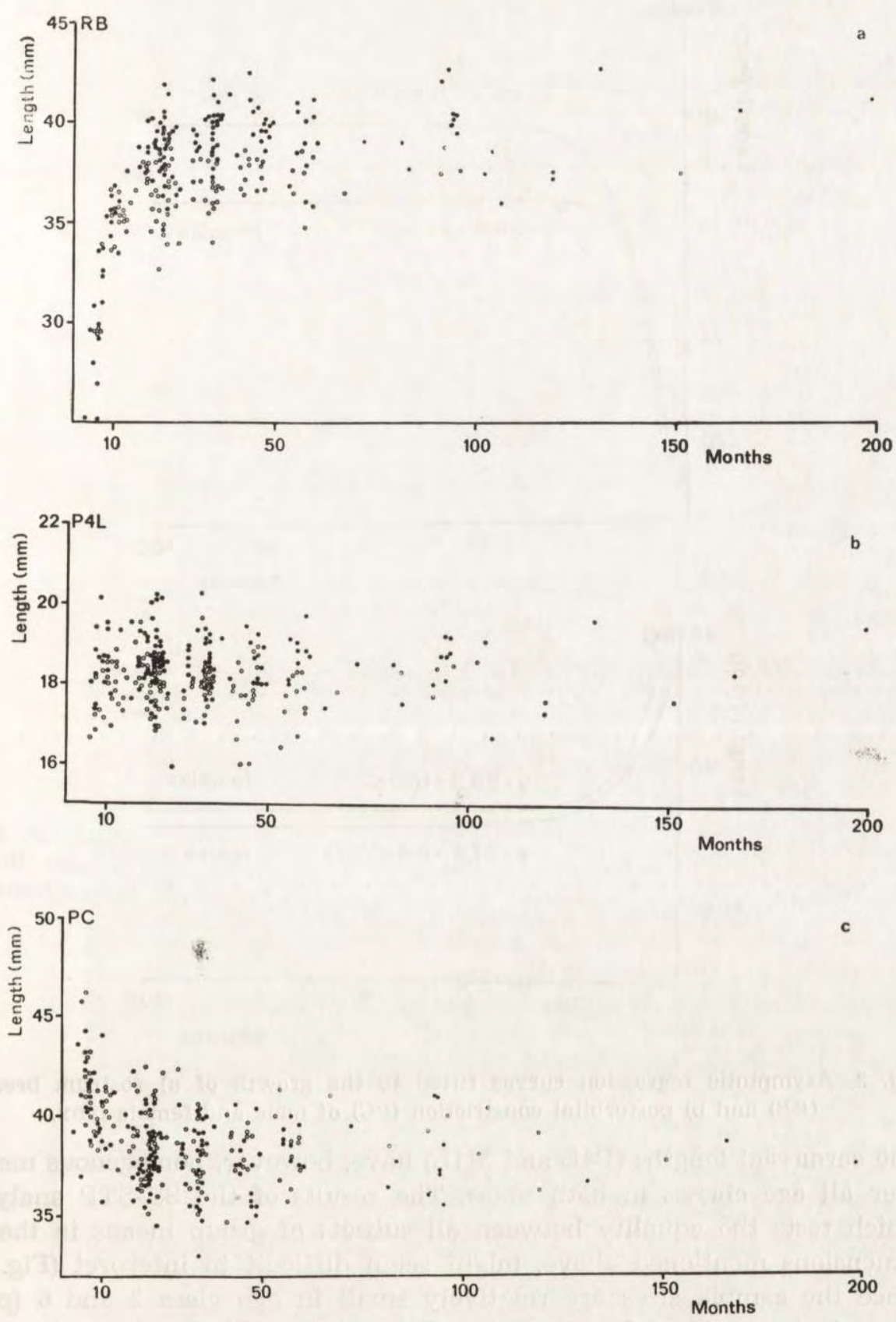

Fig. 2. a) Rostrum breadth $(R B)$, b) $P^{4}$ length $(P 4 L)$, and c) Postorbital constriction $(P C)$ ploted against age in male $(\bullet)$ and female $\left({ }^{\circ}\right)$ lynx. 

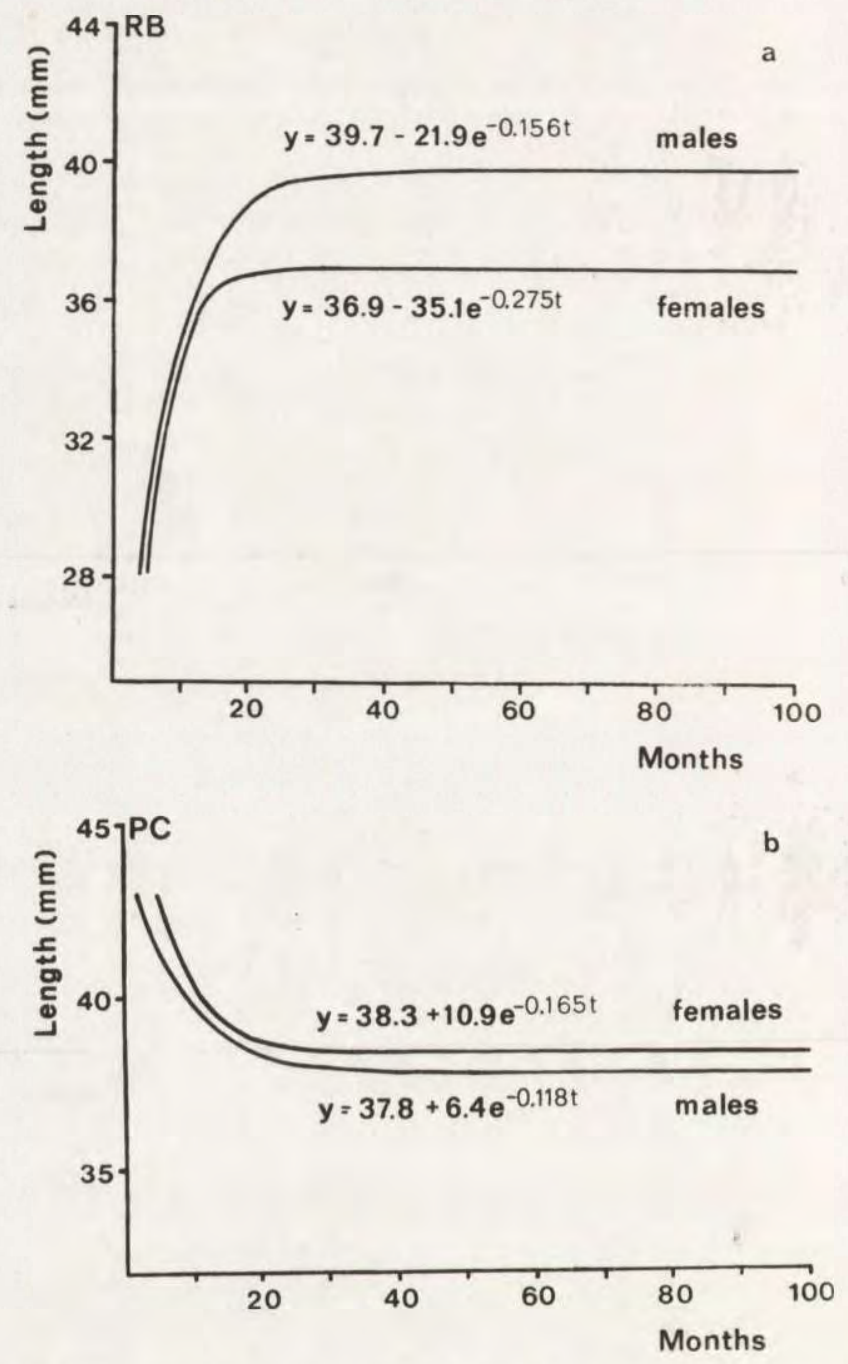

Fig. 3. Asymptotic regression curves fitted to the growth of a) rostrum breadth $(R B)$ and b) postorbital constriction $(P C)$ of male and female lynx.

The carnassial lengths (P4L and M1L) have, however, homogenous means over all age classes in both sexes. The results of the SS-STP analysis, which tests the equality between all subsets of group means in the 14 dimensions mentioned above, might seem difficult to interpret (Fig. 4). Since the sample sizes are relatively small in age class 2 and 6 (particularly in age class 2 of males) and the means of some dimensions are lesser in age class 6 than in age class 5, non-significant subsets are not necessarily adjacent. This is indicated in the figure by discontinuous lines. 


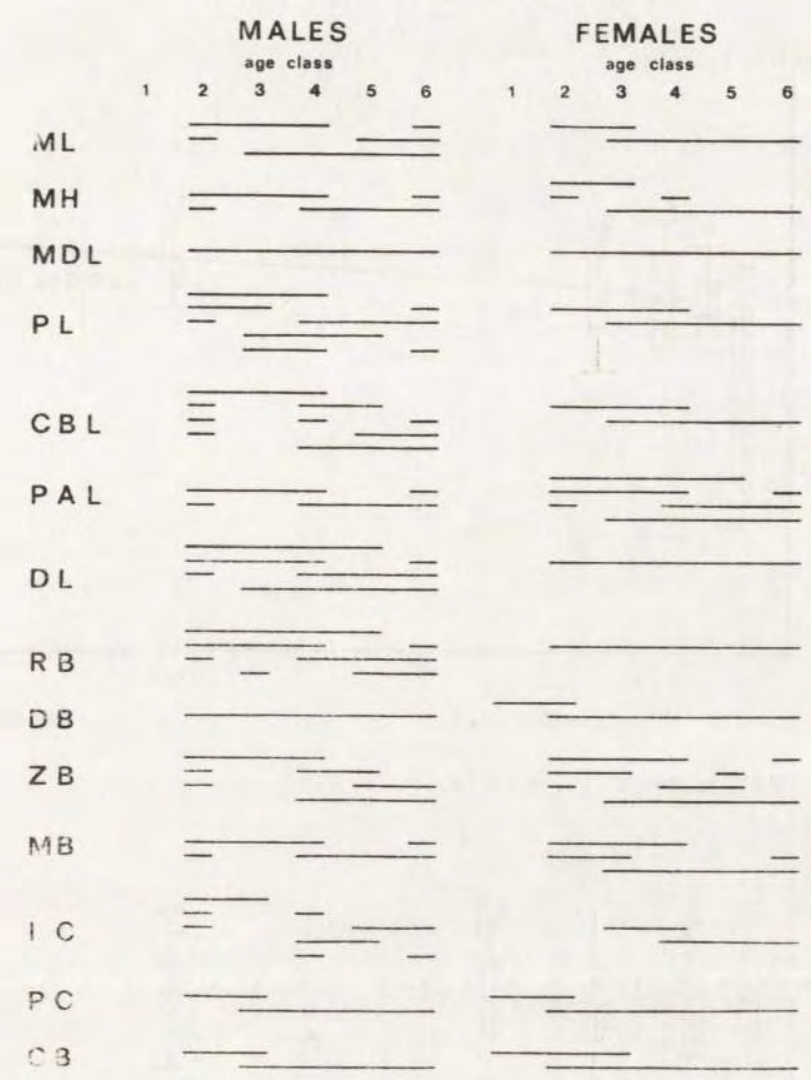

Fig. 4. Non-significant subsets of means (underlined) in six age classes of 14 skull dimensions of male and female lynx according to a SS-STP analysis. Discontinuous lines indicate that non-significant subsets not necessarily are adjacent.

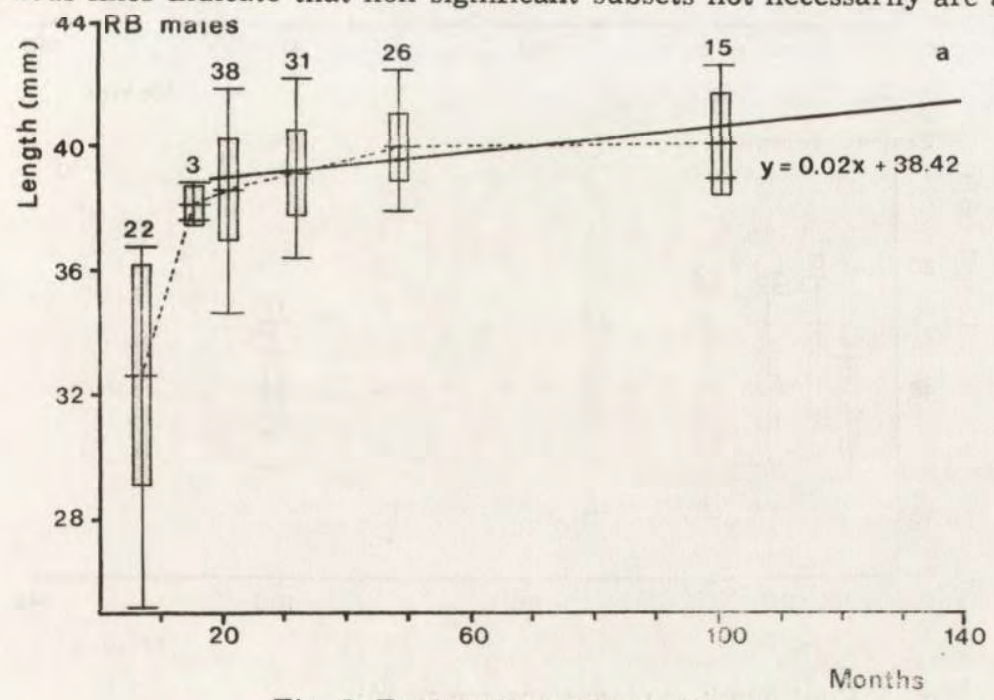

Fig. 5. Explanations see p. 101. 

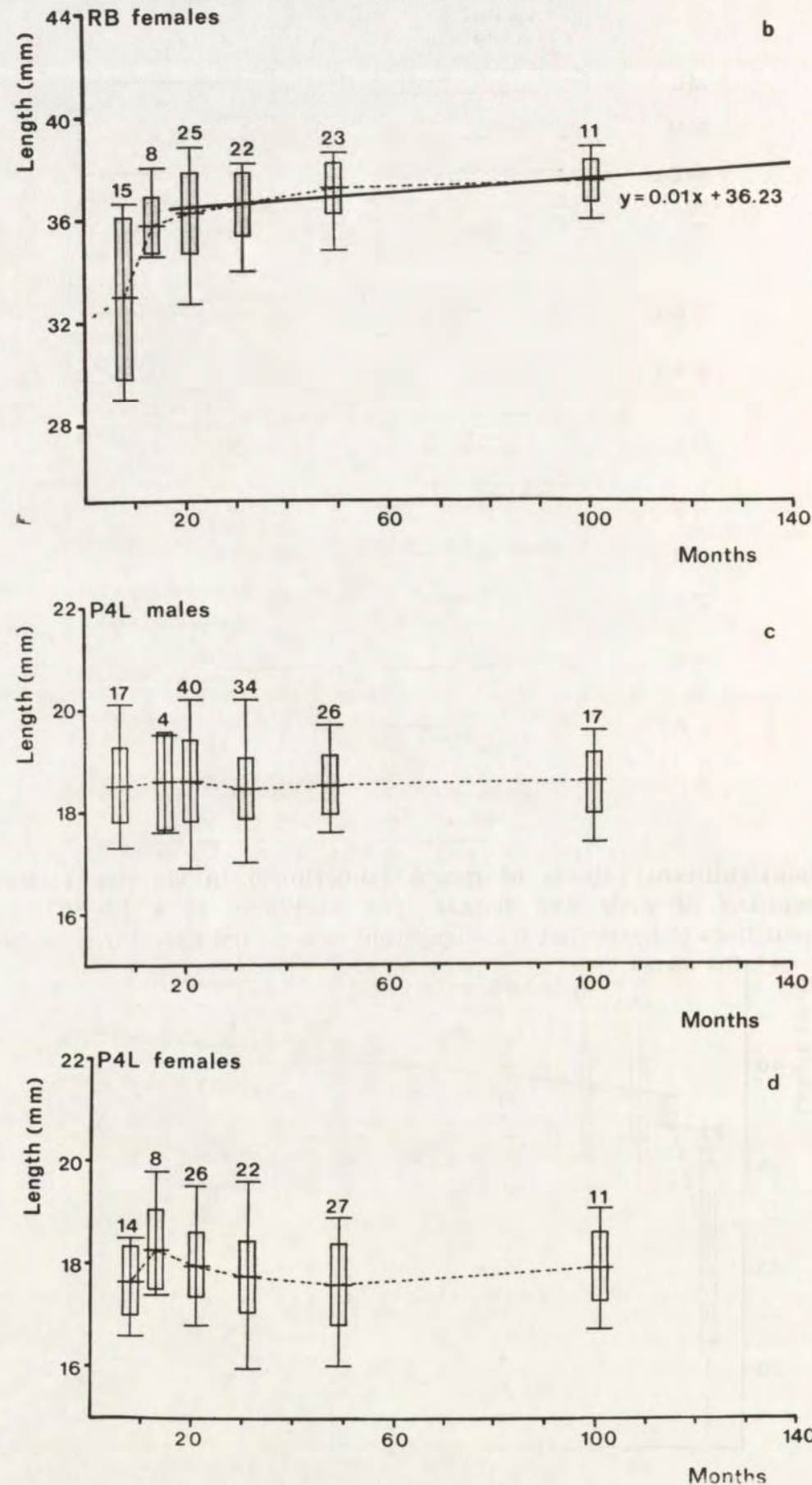

Fig. 5. Continued; explanations see p. 101. 

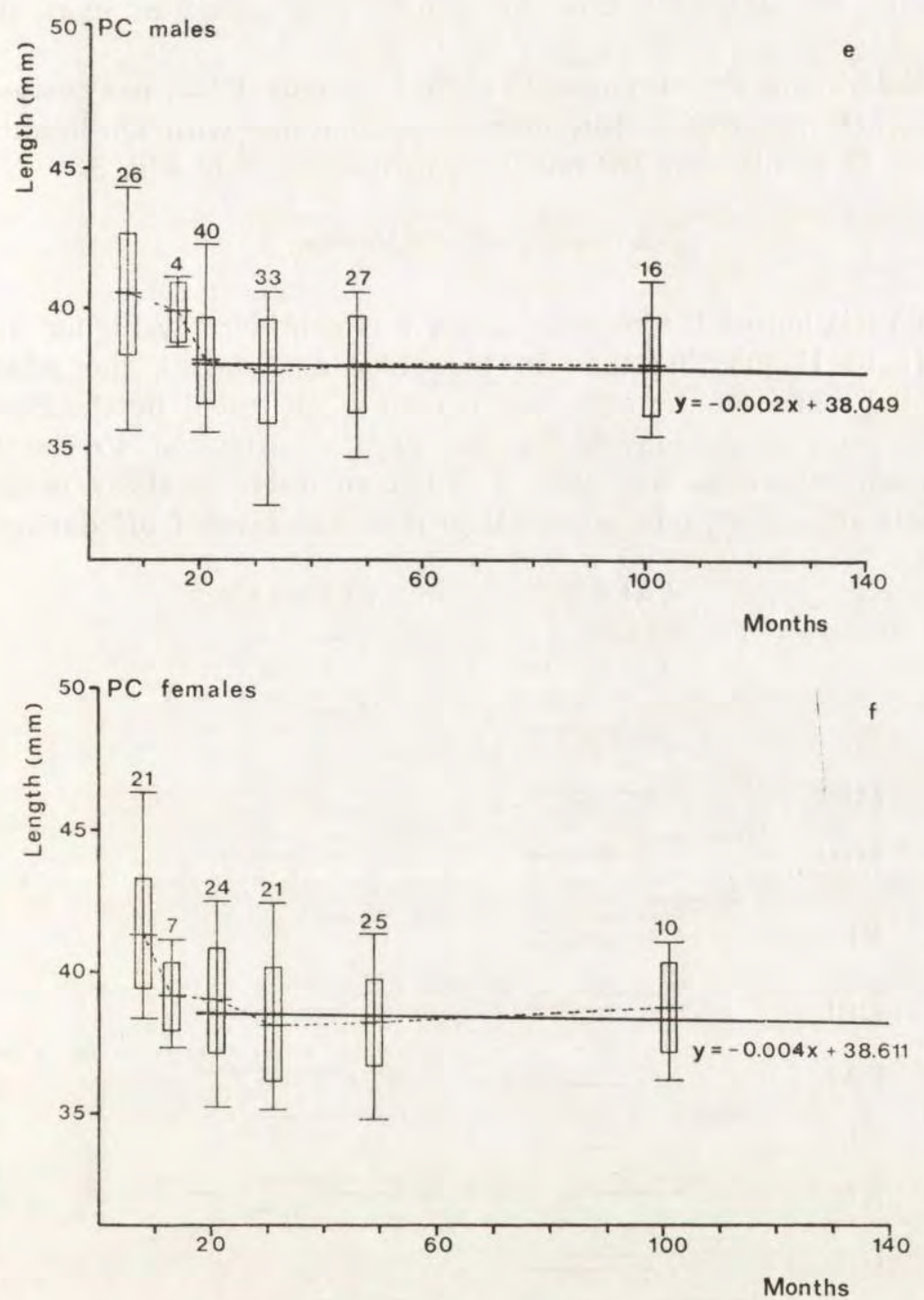

Fig. 5. Sample size, mean \pm 1 standard deviation (sheded rectangle) and range of rostrum breadth $(R B), \mathrm{P}^{4}$ length $(P 4 L)$, and postorbital constriction $(P C)$ within six age classes of male and female lynx. The statistics are situated at mean age within each class. The regression line with age of individuals older than 17 months are shown for $R B$ and $P C$.

The general result of the analysis is that in both sexes, the mean of age class 1 is significantly different from the older classes in most dimensions. During the next 6 months the growth evens out and thereafter the means of the age classes become more or less equal. The ontogenetic 
variation in animals older than 17 months is analysed in more detail below.

Basic statistics of rostrum breadth $(R B), P^{4}$ length $(P 4 L)$, and postorbital constriction $(P C)$ as well as the linear regression line with age in animals older than 17 months for $R B$ and $P C$ are illustrated in Fig. 5.

\subsection{Growth after 17 Months}

As the variation of the measurements was considerably higher in age class 1 ( 1 to 11 months) than in the older age classes, the relations between the means of the older age classes when tested by the SS-STP procedure were overshadowed by the high contribution to the total within mean square by age class 1 . Thus, in order to study in detail the growth after the rapid postnatal growth has leveled off during the

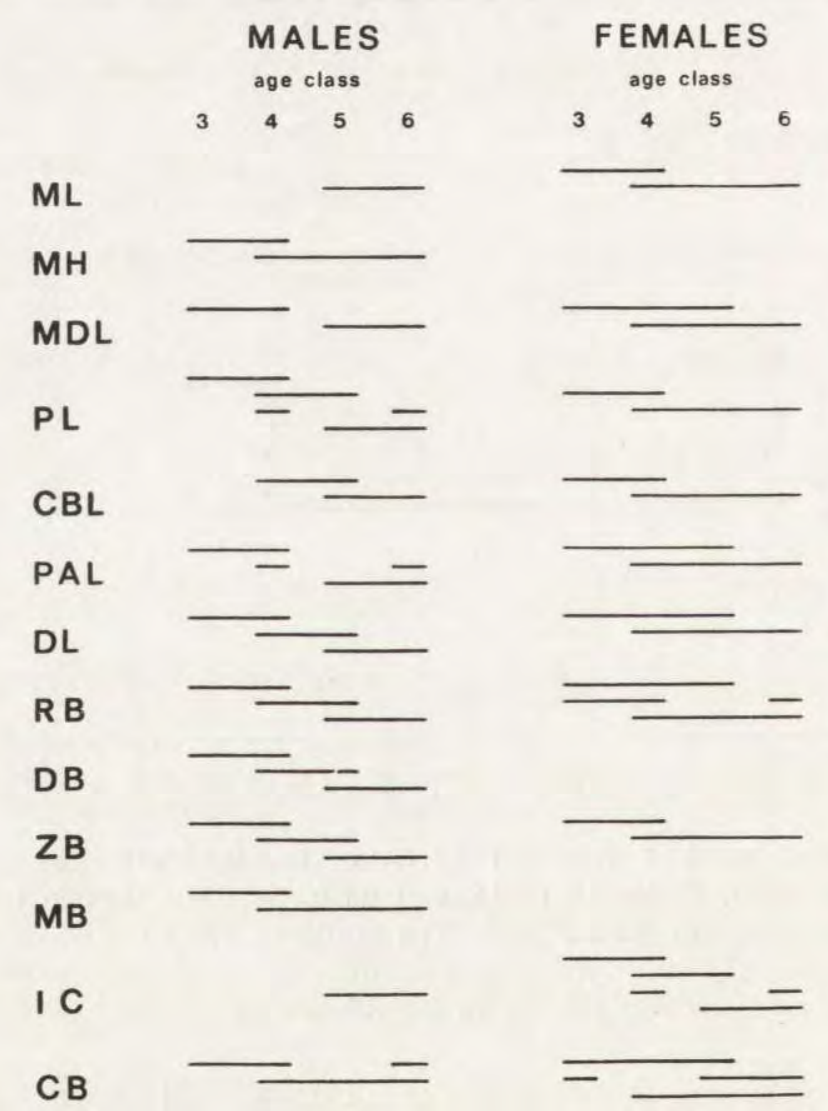

Fig. 6. Non-significant subsets of means in four age classes (older than 17 months) of 13 skull dimensions of male and female lynx according to a SS-STP analysis. Discontinuous lines indicate that non-significant subsets not necessarily are adjacent. 
first half of the second year, both an analysis of regression and a SS-STP test were applied to the four oldest age classes. The results of the regression analysis are shown in Table 2 and of the SS-STP in Fig. 6. The variation in each dimension is described in detail below. The level of significance for the SS-STP analysis is in all cases set at $5 \%$.

$\mathrm{M}$ andible length (ML). The regression with age is highly significant in both sexes $\left(P_{\text {males }}<0.001, P_{\text {temales }}<0.01\right)$. The mean of age class 6 (>59 months) in the males is somewhat less than the mean of age class 5 ( 36 to 59 months), the difference between them is, however, not significant. But the means of age class 3 (18 to 23 months) and age class 4 (24 to 35 months) both differ significantly from the means of the other three age classes.

Table 2

The significance of linear regression between 16 cranial dimensions and age in male and female lynx older than 17 months based on an analysis of variance. Significant results indicate regression coefficients different from zero.

\begin{tabular}{|c|c|c|c|c|c|c|c|c|c|c|c|c|}
\hline$M L$ & $M D L M 1 L$ & $P L$ & CBL & $P A L$ & $D L P 4 L$ & $R B$ & $D B$ & $Z B$ & $M B$ & IC & PC & CB \\
\hline Males & & & & & & & & & & & & \\
\hline $\begin{array}{l}+++++++ \\
\text { Females }\end{array}$ & +++ & +++ & +++ & +++ & +++ & t++ & +++ & ${ }^{+++}$ & +++ & +++ & & \\
\hline$++\quad+$ & +++ & ++ & ++ & ++ & ++ & ++ & & ++ & & +++ & & \\
\hline
\end{tabular}

$+: P \leqslant 0.05,++: P \leqslant 0.01,+++: P \leqslant 0.001$

In the females the mean of age class 3 differs significantly from the means of age class 5 and 6 , and the means of the three oldest age classes (age class 4, 5 and 6) constitute a nonsignificant subset.

$\mathrm{M}$ andible height $(M H)$. The regression with age is highly significant $(P<0.001)$ in the males. The mean of age class 3 differs significantly from the means of age class 5 and 6 , but the means of the three oldest classes are not significantly different. Also in this dimension the mean of age class 6 in the males is less than the mean of age class 5 .

In the females a significant regression $(P<0.05)$ is detected, but the analysis of variance shows no significant differences $(P>0.10)$ between the four oldest age classes.

Mandible dental length (MDL). The regression with age is highly significant in both sexes $(P<0.001)$. In the males the difference between the means of age class 3 and 4 and between 5 and 6 are not significant. Between the means of age class 3 or 4 and 5 or 6 , however, the differences reach significance. 
In the females the means of age class 5 and 6 are significantly larger than the mean of age class 3 .

$\mathrm{M}_{1}$ length (M1L). The regression with age and the analysis of variance of the age classes show no significant differences in either of the sexes.

$\mathrm{Pr}$ ofile length $(P L)$. The regression with age is highly significant in both sexes $\left(P_{\text {males }}<0.001, P_{\text {temales }}<0.01\right)$. In the males the mean of age class 3 differ significantly from age class 5 and 6 . Each pair of means of the three oldest age classes do not differ significantly from each other, but the three age classes do not constitute a nonsignificant subset.

In the females the only significant difference detected is between the means of age class 3 and the two oldest age classes.

$\mathrm{Condylob}$ a sal length $(C B L)$. The regression with age is highly significant in both sexes $\left(P_{\text {males }}<0.001, P_{\text {females }}<0.01\right)$. In the males the mean of age class 3 differs significantly from the means of the three older age classes. Also the difference between age class 4 and 6 reaches significance.

In the females significant differences between means are detected between age class 3 and the older age classes.

$\mathrm{Pal}$ atal length $(P A L)$. The regression with age is highly significant in both sexes $\left(P_{\text {males }}<0.001, P_{\text {females }}<0.01\right)$. In the males the mean of age class 3 differs significantly from the means of age class 5 and 6 . Significant differences between the means of age class 4 and 5 also exist, but not between 4 and 6 , due to the lower mean size of age class 6 than of 5 .

In the females significant differences are only detected between the means of age class 3 and 6 .

$\mathrm{Dental}$ le $\mathrm{ngth}(D L)$. The regression with age is highly significant in both sexes $\left(P_{\text {males }}<0.001, P_{\text {females }}<0.01\right)$. In the males the mean of age class 3 differs significantly from the means of age class 5 and 6 . Also the mean of age class 4 differs significantly from age class 6 .

In the females a significant difference between means is only detected between age class 3 and 6 .

$\mathrm{P}^{4}$ le ngth $(P 4 L)$. Neither significant regressions nor inhomogeneity between means are detected in either of the sexes.

Rostrum breadth $(R B)$. The regression with age is highly significant in both sexes $\left(P_{\text {males }}<0.001, P_{\text {females }}<0.01\right)$. In the males the mean of age class 3 differs significantly from the means of age class 5 and 6 . Also the mean of age class 4 differs significantly from age class 6.

In the females the results of the SS-STP test are difficult to interpret. 
Three nonsignificant subsets comprising the means of three age classes are detected. The mean of age class 6 constitutes together with the means of age class 3 and 4 (but not 5) a nonsignificant subset probably due to the small sample size of age class 6 .

$\mathrm{D}$ e $\mathrm{ntal}$ brea d th $(D B)$. The regression with age reaches significance in the males only $\left(P_{\text {mates }}<0.001, P_{\text {females }}>0.05\right)$. Also the analysis of variance between the means of the age classes is significant in males only $\left(P_{\text {males }}<0.001, P_{\text {females }}>0.40\right)$. In the males significant differences between means are found between age class 3 and age class 5 and 6 and between age class 4 and 6 .

$\mathrm{Zyg}$ y matic breadth $(Z B)$. The regression with age is highly significant in both sexes $\left(P_{\text {males }}<0.001, P_{\text {females }}<0.01\right)$. In the males the difference between the means of age class 3 and age class 5 and 6 , and between the means of age class 4 and 6 are significant.

In the females, the means of age class 4,5 , and 6 constitute a nonsignificant subset, differing significantly from the mean of age class 3 .

Mastoid breadth $(M B)$. The regression with age is significant in males only $\left(P_{\text {males }}<0.001, P_{\text {femates }}>0.05\right)$. Also the analysis of variance between the means of the age classes is significant in males only $\left(P_{\text {males }}<0.001, P_{\text {females }}>0.10\right)$. In the males significant differences between means are found between age class 3 and age class 5 and 6 .

Interorbital constriction (IC). The regression with age is highly significant in both sexes $(P<0.001)$. In the males age class 5 and 6 constitute the only nonsignificant subset of means.

In the females the mean of age class 3 differs significantly from age class 5 and 6 . Nonsignificant subsets of means are found between age class 4 and 5 , between 4 and 6 and between age class 5 and 6 .

Postorbital constriction (PC). This dimension does not show any age dependance in animals older than 17 months in either sex.

$\mathrm{C}$ ondy $\mathrm{l}$ breadth $(C B)$. Significant regression with age is only found in the females $\left(P_{\text {males }}>0.05, P_{\text {females }}<0.05\right)$. The analysis of variance does, however, show significant differences between the means of the age classes in both sexes. As the mean of age class 6 is less than the means of age class 4 and 5 in the males, the only significant difference between the means found in this sex is between age class 3 and 5 .

In the females the pattern of variation is somewhat confusing; the three nonsignificant subsets of means found include all possible combinations between two means.

In specimens older than 17 months the departure from a linear regression reached significance $(P<0.05)$ in ten dimensions in the males. 
and three dimensions in the females (Table 3). By excluding specimens older than 59 months from this analysis, significant departure from a linear regression is not found in any dimensions of either sex $(P>0.05)$.

\section{DISCUSSION}

Rapid growth during the early postnatal period is characteristic for most mammals, but the growth tends to level off after a shorter or longer period of time, and the animals are said to be fully grown (Thompson, 1952). Each skeletal dimension increases at a specific growth rate, which often differs from each other producing simultaneous changes both in absolute size and in relative proportions. It should be noted, however, that growth is not necessarily positive. Enlow (1963) and Moore (1981) discuss in great detail the mechanisms of growth by which these changes in skull proportions are achieved. Because of its rigidly

Table 3

Tests of significance of departure from linear regression between 16 cranial dimensions and age in male and female lynx older than 17 months.

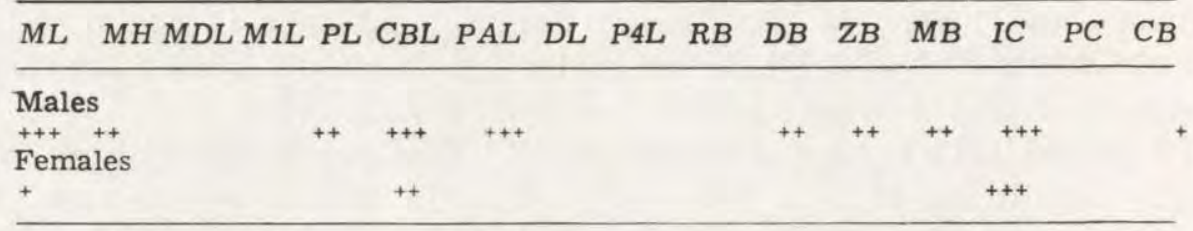

$+: P \leqslant 0.05,++: P \leqslant 0.01,+++: P \leqslant 0.001$

mineralised matrix bone can grow by surface accreation only. To prevent a progressiv distortion of the skull as growth proceeds, the addition of bone substance is accompanied by bone resorbtion, a process frequently termed as remodelling. In addition to remodelling changes at the surface, the bones receive major growth contributions from the activity of the cartilages located along the edges of the bones.

In lynx most cranial dimensions were found to increase with age, although the rate and course of the growth varied. The length of the permanent carnassials, however, were found to be constant over all age classes in both sexes. In many carnivores the canines increase in prominence with age (Churcher, 1960; Crowe, 1975), while tooth wear reduces the size of the teeth in old animals (Wood, 1958). When measured at the crown base, as in this study, eventually wear of the carnassials should not be reflected in the total length measure. The breadth of the postorbital constriction decreases with age, a phenomena that probably is associated with bone resorbtion, as demonstrated in other carnivores (e.g. Wiig, 1982). 
In lynx the growth pattern of most skull dimensions show a period of rapid growth during the first year in both sexes. In most of the dimensions age class 1 ( 1 to 11 months) deviates significantly from the older age classes. Although the males seem to grow for a longer period of time than the females the rapid growth levels off before the animals are two years of age in both sexes. Brody (1964) suggested that the time of the cessation of the rapid growth in most mammals coincides with the attainment of puberty. In European lynx the females generally are sexually mature at the age of two years, although some females might also be mature after only one year, while the males generally are mature at an age of 3 years (Kvam, 1979; Lindemann, 1955). But the onset of puberty is certainly at an earlier age, although the individual variation seems to be large. Kvam (1979) found a sexually mature female with an age of only 10.5 months, having 3 corpora lutea from a recent ovulation and an enlargened uterus, and a 10 months old male with a testes weight of $2.2 \mathrm{~g}$, which indicates that the animal was fertile. Thus the time of cessation of the rapid growth of the skull of the European lynx seems to coincide with the attainment of the puberty, and that the production of the first litter generally takes place after the animals are "fully grown".

It is often claimed that the growth in mammals is more or less deterministic, i.e. that no further growth takes place in adult specimens (e.g. Bryden, 1972), or that ontogenetic variation in adult mammals is negligible (e.g. Churcher, 1960). Age determination based on annual layering in the tooth cementum, permits studies of ontogenetic variation also in adult animals (Klevezal, 1970). King (1972) demonstrated that the male Elephant seal Mirounga leonina Linnaeus, 1758 has a steady growth at least up to an age of about eleven years, while the females more or less cease to grow after about 30 to 40 months of age. Also in other carnivores like the Red fox Vulpes vulpes (Linnaeus, 1758) particularly the males show significant tendencies to increase in size with age also after the rapid growth during the first year has ceased (Huson \& Page, 1980b).

In lynx the growth of the skull continues at a slow rate also in adult specimens. The pattern of the growth after the age of 17 months seems, however, to be different in males and females. In the males the only dimensions that did not show a significant regression with age were the carnassial lengths $(M 1 L$ and $P 4 L)$ the postorbital constriction $(P C)$ and the condyl breadth $(C B)$. All the other dimensions showed a highly significant $(p \leqslant 0.001)$ regression with age. But the growth in all skull dimensions seems to come to a complete halt at about three to four years of age. Also in the females older than 17 months the carnassial 
lengths and the postorbital constriction were not regressed to age, and in addition no further growth was found in the dental breadth $(D B)$ and the mastoid breadth $(M B)$. The other dimensions measured all were significantly regressed to age $(p \leqslant 0.05)$. In the females, however, the growth stopped at an earlier age than in the males. This difference is also reflected in the lower levels of significance of the regression between the skull dimensions and age in females than in males. The sexrelated growth pattern has relations to the pronounced sexual sizedimorphism in the lynx, which we discuss elsewhere (Wiig \& Andersen in press).

When studying the affinities of populations it is necessary to prevent nongeographic intraspecific variation from confusing the geographic pattern of variation (Thorpe, 1976). The main sources of genetically controlled nongeographic variation is variation due to sex and age (Straney, 1978). Sexual dimorphism can be dealt with simply by keeping the sexes separate from the outset and analysing each sex independently, while variation due to ageing is generally more difficult to eliminate. In studies on geographic variation, ontogenetic variation, if considered at all, is often handled by using samples of "fully matured specimens" only (e.g. Kratochvil, 1977), or by securing that the samples from the different populations have a similar age structure (e.g. Huson \& Page, 1980a). The present study clearly demonstrates that in lynx, a slow growth takes place in adult specimens also. In lynx and other longlived carnivores it seems therefore desirable to use statistical methods adjusting for these ageinduced differences, particularly when geographic variation betwen adjacent populations is studied.

Acknowledgement: We want to thank Mrs. M. Bravo, Zoological Museum, University of Bergen, for the tedious work of making and punching the measurements. We are also indebted to Mr. S.-P. Soulere, The Computer Centre, University of Bergen, for comprehensive help with processing the data, and Mrs. A. Ree for typing the manuscript.

\section{REFERENCES}

1. Brody S., 1964: Bioenergetics and growth with special reference to the efficiency complex in domestic animals. Hafner Publishing Company: 1-1023. New York.

2. Bryden M. M., 1972: Growth and development of marine mammals. [In: "Functional anatomy of marine mammals", vol. 1. R. J. Harrison, ed.]. Academic Press: 1-79. London, New York.

3. Churcher C. S., 1960: Cranial variation in the North American Red fox: J. Mammal., 41: 349-360.

4. Cock A. G., 1966: Genetical aspects of metrical growth and form in animals. Quart. Rev, Biol., 41: 131-190.

5. Crowe D. M., 1975: Aspects of aging, growths and reproduction of Bobcats from Wyoming. J. Mammal., 56: 177-198. 
6. Dixon W. J., 1981: BMDP Statistical Software 1981. University of California Press: $1-725$. Berkeley. Los Angeles. London.

7. Dudzinski M. L. \& Mykytowycz R., 1961: The eye lens as an indicator of age in wild rabbit in Australia. C.S.I.R.O. Wildl. Res., 6: 156-159.

8. Enlow D. H., 1963: Principle of bone remodelling. C. Thomas: 1-437. Springfield, Illinors.

9. Friend M., 1967: A review of research concerning eye-lens weight as a criterion of age in animals. New York Fish Game J., 14: 152-165.

10. Gabriel K. R., 1964: A procedure for testing the homogeneity of all sets of means in analysis of variance. Biometrics, 20: 459-477.

11. Gould H. N. \& Kreeger F. B., 1948: The skull of the Luisiana muskrat (Ondatra zibethica rivalicia Bangs): 1 . The skull in advanced age. J. Mammal., 29: $138-149$.

12. Grue H. \& Jensen B., 1979: Review of the formation of incremental lines in tooth cementum of terrestrial mammals. Danish Rev. Game Biol., 11: 1-48.

13. Hagen A., Stenseth N. C., Østbye E. \& Skar H.-J., 1980: The eye lens as an age indicator in the root vole. Acta theriol., 25: 39-50.

14. Hewer H. R., 1964: The determination of age, sexual maturity, longevity and a life-table in the Grey seal (Helichoerus grypus). Proc. Zool. Soc., Lond., 142: $593-623$.

15. Huson L. W. \& Page R. J. C., 1980a: Multivariate geographical variation of the Red fox (Vulpes vulpes) in Wales. J. Zool., Lond., 191: 453-459.

16. Huson L. W. \& Page R. J. C., $1980 \mathrm{~b}$ : Age related variability in cranial measurements in the Red fox (Vulpes vulpes). J. Zool., Lond., 191: 427-429.

17. Hysing-Dahl C., 1959: The Norwegian otter Lututra lututra (L.), a craniometric investigation. Univ. i Bergen Årb. Naturv. Rek., 1959, 5: 1-44.

18. Kidwell J. F., Herbert J. G. \& Chase H. B., 1979: The inheritance of growth and form in the mouse. V. Allometric growth. Growth, 43: 47-57.

19. King J. E., 1972: Observations on phocid skulls. [In: "Functional anatomy of marine mammals". vol. 1. R. J. Harrison, ed.]. Academic Press: 80-115, London, New York.

20. Klevezal G. A., 1970: A retrospective evaluation of the individual features of mammal growth based on the structure of dentine and bone layers. Ontogenez, 1: 362-372, (Translated).

21. Kratochvíl J., 1977: Studies on Mustela erminea (Mustelidae, Mamm.) I. Variability of metric and mass traits. Folia Zool., 26: 291-304.

22. Kvam T., 1979: Reproduksjonsforhold og populasjonsstruktur hos Norsk Gaupe $\operatorname{Lynx} \operatorname{lynx}$ (L.). Univ. of Trondheim: 1-72. Trondheim. [Unpubl. cand. real. thesis].

23. Lindemann W., 1955: Uber die Jugendentwicklung beim Luchs (Lynx l. lynx Kerr.) und bei der Wildkatze (Felis s. silvestris Schreb.). Behaviour, 8: 1-45.

24. Lombaard L. J., 1971: Age determination and growth curves in the black-backed jackal, Canis mesomelas Schreber, 1775 (Carnivora: Canidae). Ann. Transv. Mus., 27: 135-169.

25. Moore W. J., 1981: The mammalian skull. Cambridge Univ. Press: 1-369. Cambridge.

26. Morris P., 1972: A review of mammalian age determination methods. Mammal Rev., 2: 69-104.

27. Reimers E. \& Nordby Ø., 1968: Relationship between age and tooth cementum layers in Norwegian reindeer. J. Wildl. Manage., 32: 957-961. 
28. Simpson G. G., Roe A. \& Lewontin R. C., 1960: Quantitative zoology. Harcourt Brace and Company: 1-440. New York, Burlingame.

29. Sokal R. R. \& Rohlf F. J., 1969: Biometry. 1st ed. W. H. Freeman and Company: 1-776. San Francisco.

30. Sokal R. R. \& Rohlf F. J., 1981: Biometry. 2nd ed. W. H. Freeman and Company: 1-859. San Francisco.

31. Stephenson A. B., 1977: Age determination and morphological variation of Ontario otters. Can. J. Zool., 55: 1577-1583.

32. Straney D. O., 1978: Variance partitioning and nongeographic variation. J. Mammal., 59: 1-11.

33. Tanner J. M., 1951: Some notes on the reporting of growth data. Human Biol., 23: 93-159.

34. Thompson D. W., 1952: Growth and form. vol. 1. 2nd ed. Cambridge Univ. Press: 1-464. London, New York.

35. Thorpe R. S., 1976: Biometric analysis of geographic variation and racial affinities. Biol, Rev., 51: 407-452.

36. Wallon K. C., 1968: The baculum as an age indicator in the polecat Putorius putorius. J. Zool., Lond., 156: 533-536.

37. Wiig Ø., 1982: Bone resorption in the skull of Mustela vison. Acta theriol. 27: $358-360$.

38. Wiig $\varnothing$. \& Andersen T., 1984: Sexual size dimorphism of Scandinavian lynx (Lynx lynx). Holarct. Ecol., in press.

39. Wood J. E., 1958: Age structure and productivity of a Grey fox population. J. Mammal., 39: 74-86.

Accepted, November 16, 1983.

Trond ANDERSEN i Øystein WIIG

\section{WZROST CZASZKI LYNX LYNX Z NORWEGII}

\section{Streszczenie}

Na podstawie 16 pomiarów badano zmienność wiekową czaszki rysia (Ryc. 1). Materiał składał się z 281 czaszek (156 samców i 125 samic) zwierząt złowionych w różnych częściach Norwegii w okresie od 1960 do 1969 roku. Stwierdzono istnienie trzech głównych wzorców rozwojowych: większość wymiarów czaszki zwiększała się $\mathrm{z}$ wiekiem zwierzęcia, podczas gdy długości łamaczy nie były uzależnione od wieku, a szerokość zwężenia zaoczodołowego obniżała się $\mathrm{z}$ wiekiem (Ryc. 2). Wszystkie wymiary zwiększające się z wiekiem wykazują okres gwałtownego wzrostu w pierwszym roku życia rysia, po czym w pierwszej połowie drugiego roku ich wzrost ulega zwolnieniu. Obniżanie się z wiekiem pomiarów zwężenia zaoczodołowego wykazuje odwrotny rytm. Oznacza to, że faza szybkiego wzrostu kończy się w okresie osiągnięcia dojrzalości płciowej. Kilka pomiarów czaszki wykazuje słaby lecz stały wzrost także u zwierząt ponad 17-miesięcznych (Ryc. 6). Ten wzrost badano szczegółowo drogą analizy regresji w poszczególnych klasach wieku (Ryc. 3, 4 i 5). Wzorzec wzrostu u samców i samic wydaje się być różny. Czaszki samców rosną ciągle do 3 lub 4 roku życia, podczas gdy czaszki samic zatrzymują się w rozwoju w wieku około 2 lat. Przedyskutowano też implikacje ontogenetycznej zmienności rysi na badania zmienności geograficznej. 